\title{
Implementation of the EU Horizontal Policies in Ukraine in the Framework of the EU-Ukraine Association Agreement
}

Keywords: EU Common Policies, EU Horizontal Policies, EU Regional Policy, EU Social Policy, EU Tax Policy, EU Competition Policy, EU Environmental Policy, the EU-Ukraine Association Agreement

\begin{abstract}
The EU Horizontal Policies and their impact on the relations with third countries have been investigated based on the EU-Ukraine Association Agreement. The essence and role of the EU common policies and the place of horizontal policies within their structure are analysed here. Special attention is paid to the EU-Ukraine cooperation in the framework of the Association Agreement and responsibilities of Ukraine in the process of the law approximation and policy implementation followed by analyses of the achievements, challenges, and further perspectives for their bilateral cooperation in the conclusion.
\end{abstract}

* ORCID ID: https://orcid.org/0000-0001-6997-3490, Candidate of Political Sciences $(\mathrm{PhD})$, Associate Professor of the Department of Regional Studies and International Tourism, Faculty of International Relations, Ivan Franko National University of Lviv, Ukraine. Senior Research Fellow, IFNUL Jean Monnet Centre of Excellence "Western Ukrainian Research Centre for European Studies" (starting from 2018). Senior Sectoral Policy Fellow, the EU Project "Support for the implementation of the EU-Ukraine Association Agreement" (Association4U, 2017-2019). Member of the Ukrainian Association of Professors and Researchers of European Integration (APREI, since 2018). Member of the Ukrainian European Studies Association (UESA, since 2010). Expert in political and economic aspects of European Integration, Common Policies of the EU, the process of the EU enlargement, European Union Policy in the sphere of Tourism, EU-Ukraine relations, Educational Policy of the EU, International Project management. The author of more than 50 scientific publications. Web-page: https://intrel.lnu.edu. ua/employee/krajevska-oksana-anatolijivna E-mail: oksana.krayevska@lnu.edu.ua 


\section{Introduction}

European integration is based on common policies that are developing and multiplying through a specific internal decision-making process, which reflects the peculiarities of integration processes. The issues of formation and implementation of the EU Common Policies (hereafter - EU CPs), the possibility of joint activities in various spheres, and coherent improvement of institutional policy-making mechanisms are of great importance for the study of the European integration processes.

This article seeks to investigate the place and role of the EU Horizontal Policies in the framework of the EU Common Policies, explore their theoretical and methodological backgrounds from the perspective of ensuring the EU's proper functioning at the present stage.

The main research question concerns the scope, content, and binding nature of Ukraine's obligations following from the EU-Ukraine Association Agreement (hereafter - AA) from the perspective to ensure due to AA implementation and support of the introduction of effective policymaking processes in Ukraine based on the European experience and best practices.

The first part of the article is dedicated to the presentation of the EU Common Policies and EU Horizontal Policies (hereafter - EU HP) as identified by Nikolas Moussis in his work Guide to European policies ${ }^{1}$. These policies concern five areas such as regional development, taxation, competition, environmental and social policy and are deemed to be fundamental for the social and economic growth in the EU. They influence other EU Common Policies, as the EU HP aspects should be considered whenever any decision at the EU level is taken and dully reflected in all activities implemented in the EU.

The understanding of these fundamental issues in the decisionmaking in the EU is crucial for Ukraine as the country which is trying to receive green light for the EU membership and fosters the AA implementation especially focusing on the legal approximation to the European norms and standards. This understanding will influence the policy-making process in Ukraine and develop the road map for effective cooperation in different spheres.

The cooperation between the EU and Ukraine in the sphere of the EU HPs is analysed in the context of the AA implementation agenda focusing on the challenges for the effectiveness and efficiency of the

1 N. Moussis, Guide to European policies, European Study Service, Rixensart 2005. 
policy-making in Ukraine. The trade and trade-related issues as well as sectoral and economic cooperation with the EU are paid special attention in the second part of the article. The scope of the main duties and responsibilities of Ukraine in the process of the legal approximation and national policy about the AA implementation are determined and analysed here.

As the hypotheses we can presume that the European Union will demand from Ukraine the same style and understanding of the policymaking process as it has for its member-states. Thus, the EU-styled models of the policy-making will influence the style of the EU-Ukraine activities towards the AA implementation, especially when the legal approximation and the implementation of the European standards and norms is concerned.

This contribution is based on the analysis of the above-mentioned issues in the provisions of the EU Treaty, AA, and Reports on its implementation together with political documents, media and other sources combined with the content, and event analysis using historical and forecasting approaches. The main achievements and challenges are determined and further perspectives are elaborated in the conclusion.

\section{EU Common Policies: \\ Theoretical and Methodological Foundations of Their Formation and Implementation}

EU Common Policy is a widely used term to describe the EU activities in different areas of the EU's activities. EU CPs as a phenomenon evolved historically. The theoretical basis for the study of the EU CPs is introduced by the theory of European integration and is linked to main political science approaches developed by Jean Monnet vision on integration method in EU governance model, by Haas and Mitrani's discourse on spill-over effect as part of the early neo-functionalist debate and contemporary neo-functionalist concepts of March, Olsen ${ }^{2}$.

Being widely used, the EU CPs as a term needs a definition, describing the patterns of the EU's external and internal conduct as an inter-

2 O. Krayevska, Common Policies of the European Union, [in:] M. Malskyy, Y. Moroz (eds.), International Relations: Politics. Economics. Law, LNU Franka, Lviv 2017 (in Ukrainian), pp. 213-228; M. Malskyy, N. Antonyuk, M. Gladysh, O. Krayevska, Regionalism and spillover effects: case of Ukraine, [in:] O. Bogdanova, A. Makarychev (eds.), Baltic - Black Sea Regionalism: Patchworks and Networks at Europe's Eastern Margins, Springer, Tartu 2020, pp. 207-224. 
national actor. EU Common Policies are mainly defined within the lines of the subject-matters they are supposed to address (e.g. Common Agricultural Policy is defined as the system in the European Union for setting prices for farm products and limits on the amounts that can be produced, and for organizing various payments to farmers ${ }^{3}$, whereas the EU Common Commercial Policy is understood as the uniform EU's action in the international trade, etc.), so that it is quite difficult to define this term precisely.

However, several attempts to propose the basic definitions have been made, mainly focusing on the EU Common Policies as the governance phenomenon. Thus, N. Moussis defines a common policy (EU CP) as a set of decisions, rules, measures and codes of conduct adopted by common institutions that were founded by a group of states and implemented by joint institutions and the Member States ${ }^{4}$. The policy has to be pursued by all members, through supranational executive and judicial authorities intended for controlling its implementation. Therefore, the common policy becomes an instrument of transferring some of sovereign national powers to supranational institutions. Such delegation of sovereign rights within the framework of common policies is a fundamental characteristic of the European integration. This explains the complexity of the adoption and implementation of any EU common policy within the EU and its importance for the whole integration structure. Consequently, common policies, as developed in the EU, distinguish European integration from interstate cooperation in terms of governance ${ }^{5}$.

In the similar direction I. Hrytsiak argues, that since the EU integration is based on a complex of diverse European governance methods both at the EU and national levels, this complexity is reflected in the EU Common Policies, in the ways they are formed, adopted and fulfilled $^{6}$. Addressing the EU CPs as a governance phenomenon, I. Hrytsiak points out the dynamic nature of the integration processes within

3 Common Agricultural Policy, Cambridge Dictionary, https://dictionary.cambridge.org/dictionary/english/common-agricultural-policy?q=common+ policy $(17.03 .2020)$.

4 N. Moussis, Use pro spilni polityky Yevropeiskoho Soiuzu, K.I.S., Kyiv 2005, 466 pp.; N. Moussis, Access to European Union: law, economics, policies, Rixensart 2011, http://europedia.moussis.eu/about/?book=B0001 (17.03.2020); N. Moussis, Guide to European policies, European Study Service, Rixensart 2005.

5 N. Moussis, Use pro spilni polityky Yevropeiskoho Soiuzu...; N. Moussis, Access to European Union...; N. Moussis, Guide to European policies...

6 I.A. Hrytsiak, Osoblyvosti yevropeiskoho upravlinnia na natsionalnomu rivni: metodychnyi aspect, «Stratehichni priorytety» 2007, No. 1 (2), pp. 165-172, http://old.niss.gov.ua/book/ StrPryor/2/5-1-Hrytsiak.pdf (17.03.2020). 
the EU while stressing that the EU governance model is based upon the vital and dynamic contest between integrational governance models, aimed to ensure the development of the EU, and the national governance approaches. These components in the EU governance, which are linked basically at the institutional level, make the EU integration model unique $^{7}$.

W. Wallace approaches the EU Common Policies discourse from the perspective of the policy-making within the governance studies perspective and argues that country-defined policy demands and policy capabilities are set in a shared European framework to generate collective regimes, most of which are then implemented back in the countries concerned. Moreover, as we shall see from several of the case studies, how those European regimes operate varies a good deal between one EU member state and another. In other words, the EU policy process is one which has differentiated outcomes, with significant variations between countries 8 .

Thus, as N. Moussis states, the EU CPs is a governance phenomenon, based on the delegation of national powers and functions, to the EU institutions, and reflected in the EU constituent treaties and other regulatory documents. The EU CPs' joint aims are mainly defined by mutual understanding between the EU Member States and EU institutions, whereas the exact task for the intergovernmental cooperation might be defined both at the level of the interactions between the EU and its Member States or by the EU institutions solely. Thus, setting-up the priorities framework of the EU CPs has a contractual nature. However, the steps to accomplish these tasks and to create the conditions for EU CPs' fulfilment are developed and implemented by the special governance methods, where the so-called Community method is the most used one ${ }^{9}$.

The EU has, since its inception, been active in a rather wide array of policy domains, and indeed has over the decades extended its policy scope. Most international or transnational regimes are more onedimensional. The part of Wallace's contention is that this array of policy

7 Ibidem, pp. 165-172.

8 W. Wallace, Tvorennia polityky v Yevropeiskomu Soiuzi, Osnovy, Kyiv 2004, 871 pp.; H. Wallace (ed.), Policy-Making in the European Union, Oxford University Press 2005, 570 pp.

9 K. Armstrong, The Character of EU Law and Governance: From 'Community Method' to New Modes of Governance, «Current Legal Problems» 2011, Vol. 64, No. 1, pp. 179-214; Queen Mary School of Law Legal Studies Research Paper No. 118/2012, https://ssrn.com/ abstract $=2067317(17.03 .2020)$. 
domains has generated not one, but several modes of policy-making, as the case studies reveal. Moreover, the same EU institutions and the same national policy-makers have different characteristics, exhibit different patterns of behaviour, and produce different kinds of outcome, depending on the policy domain and depending on the period. Thus, as we shall see, there is no single and catch-all way of capturing the essence of EU policy-making. All generalizations need to be nuanced, although five main variants of the policy process can be identified ${ }^{10}$.

According to W. Wallace, the EU CPs are shaped by five policy-making models used in the EU to achieve jointly defined integration aims: 1) special method of the Community; 2) regulatory model; 3) multilevel system of state governing; 4) trans-governmental model; 5) policy coordination $^{11}$. Their appellations reveal the informative workload of each model, differing not only in the policy-making as such but also in the level of the institutional involvement at the EU side and the EU Member States respectively. Importantly, these models make it possible to understand the differences between different EU policies.

Due to the reform of the founding treaties lead by the Treaty of Lisbon (signed in 2007 and entered into force in 2009), the "new" EU became an integration model with a relatively simple internal structure by eliminating the "three-pillar construction". The Treaty of Lisbon systematizes the basic principles of the EU's competence, for the first time identifying the most important principle of its functioning as a political power - the principle of conferral. It emphasizes the contractual origin, nature and source of the EU powers, known also as the EU competences, thus, incorporates doctrinal approaches towards their nature and classifications.

Hence, the reformed EU is endowed with the competences from the Member States that enable the EU to regulate integration processes within the EU and to take an active part in international relations. The legal bases of competences are set out in the constituent treaties and case-law of the European Court of Justice (hereafter - ECJ). The European Union cannot change its competence on its own. The EU competences have been classified in doctrine as internal (aimed to regulate relations within the EU, its Member States) and external (aimed to regulate EU's conduct on internal arena vis-à-vis third parties), explicit (expressis

10 H. Wallace, W. Wallace, M. Pollack (eds.), Policy-Making in the European Union, Oxford University Press 2005, p. 46.

11 W. Wallace, Tvorennia polityky...; H. Wallace, W. Wallace, M. Pollack (eds.), Policy-Making in the European Union... 
verbis reflected in the founding treaties) and implicit (assumed on the basis of the contractually foreseen powers and executed on the basis of the secondary EU legislation) ${ }^{12}$. Both explicit and implicit, the competence may be exclusive, shared with the Member States, supporting and special. These types of competences influence the EU policy-making models, including the EU CP subject areas, and determine their future development ${ }^{13}$.

These types of competences influence the EU's common policymaking models and determine their future development. We can see the reflection of five models proposed by W. Wallace in three types of competences according to the Lisbon Treaty. Based on the analysis, we can conclude that the special method of the Community and regulatory model are partly reflected in the exclusive competence of the EU; multilevel system of state governing and trans-governmental model - in the shared and special competences; policy coordination can be seen in the supporting competence of the $\mathrm{EU}^{14}$. This gives us possibility to understand the EU policy-making process and further activities toward its implementation by the EU and its Member States in different spheres and big variety of the EU CPs.

N. Moussis distinguishes four main types of EU CPs: basic and secondary, horizontal and sectoral. The basic EU CP can also be called a framework common policy because its main objective and the scope are determined directly in the EU founding treaties, and therefore should be coordinated with all parties ${ }^{15}$. The secondary EU CPs are developed by the EU institutions within the basic EU CPs using EU legislative framework and the EU policy-making rules. Both basic and secondary EU CPs are classified according to their relative importance, depending on fields to which they apply.

The EU sectoral common policies (hereafter - EU SCPs) are related to the largest sectors of the EU's economy and the Member States: industry, research, energy, transport and agriculture. Unlike for the industry and research, in the last three sectors, the EU founding treaties required

12 V. Muraviov, Vydy kompetentsii reformovanoho Yeuropeiskoho Soiuzu, «Visnyk Kyivskoho natsionalnoho universytetu imeni Tarasa Shevchenka. Seriia mizhnarodni vidnosyny» 2009, vyp. 37, pp. 53-58, www.nbuv.gov.ua/portal/natural/vknu/mv/2009_37.pdf (17.03.2020).

13 N. Moussis, Guide to European policies...; N. Moussis, Use pro spilni polityky Yevropeiskoho Soiuzu...

14 O.A. Krayevska, Transformatsiia modelei formuvannia spilnykh polityk YeS u kompetentsii YeS za Lisabonskym dohovorom, «Visnyk Lvivskoho universytetu. Seriia mizhnarodni vidnosyny» 2016, vyp. 38, pp. 70-79.

15 N. Moussis, Use pro spilni polityky Yevropeiskoho Soiuzu... 
to introduce a common policy. Since the whole process of multinational integration had been aimed directly at restructuring and enhancing the competitiveness of the EU industry, the EU Industrial Policy becomes as much important as other treaty-based EU SCPs. The implementation of joint research activities and energy policy is partly foreseen by sectoral agreements, uppermost by the Treaty establishing the European Atomic Energy Community (EURATOM). The difference in the legal bases of the common policies in different sectors of the economy has led to differences in their development. In addition, these divergences have resulted in different Member States' requirements towards these policies at different historical stages - the Customs Union stage, the Common Market stage, the Economic and Monetary Union stage, the Internal Market Stage and the Digital Market Stage.

As N. Moussis argues, the EU HPs are policies that affect the general conditions of Member States' economies and societies and concern five broad sectors of economic and socio-political activity at the EU level and include regional development, social progress, taxation, competition and environmental protection. All these common policies have been launched during the stages of the Customs Union and the Common Market and are being continuously developed to the further and higher goals set for the stages of Economic and Monetary Union and political integration ${ }^{16}$.

Thus, the EU CPs are linked with the governance models in the $\mathrm{EU}$ and reflect the EU and EU Member States interactions models for achieving the joint objectives of the European integration as reflected in the EU constituent treaties. The EU CPs have contractual nature and are linked both to the EU powers and policy-making rules. As the main criteria for the EU CPs classification can be suggested their embedment into the EU legal framework (foreseen or not foreseen in the EU founding treaties), the level of the institutional involvement from the EU side and their member states to policy development and policy realization, as well as their monosectoral or cross-sectoral impact within the development of the EU economic model. The EU HPs are the most evident cross-sectoral links and impact since they cover such areas as regional development, social policy, competition, taxation, and environment.

16 Ibidem. 


\section{EU Horizontal Policies: Specifics of Five Spheres}

According to the Lisbon Treaty, the EU HPs belong to the shared competence with the Member States. It is stated that the EU shall promote economic, social and territorial cohesion, and solidarity among Member States. When the Treaties confer on the EU a competence shared with the Member States in a specific area, the Union and the Member States may legislate and adopt legally binding acts in that area. The Member States shall exercise their competence to the extent that the Union has not exercised its competence. The Member States shall again exercise their competence to the extent that the Union has decided to cease exercising its competence (Art. 2A, Lisbon Treaty). Shared competence between the Union and the Member States applies to such sphere which we know as the EU HPs as: social policy, for the aspects defined in this Treaty; economic, social and territorial cohesion; environment; internal market: consumer protection (Art. 2C, Lisbon Treaty). The Union may take initiatives to ensure coordination of Member States' social policies (Art. 2D, Lisbon Treaty).

The EU shall define and pursue common policies and actions, and shall work for a high degree of cooperation in all fields of international relations, in order to foster the sustainable economic, social and environmental development of developing countries, with the primary aim of eradicating poverty; help develop international measures to preserve and improve the quality of the environment and the sustainable management of global natural resources, in order to ensure sustainable development (Art.10A, Lisbon Treaty) ${ }^{17}$. The Common Regional Policy by means of the Structural Funds aims to help the poorer EU regions to face the increased trade and competition pressure from more developed regions, arising from the obligation to create the Internal Market and the Economic and Monetary Union ${ }^{18}$. The existence of an Economic and Monetary Union, where states are deprived of the ability to influence the exchange rate and thus balance the national economy, could be detrimental to the poorer Member States until an effective regional policy built around sufficient investment from rich to poor EU regions will not be existing.

17 Treaty of Lisbon amending the Treaty on European Union and the Treaty establishing the European Community, signed at Lisbon, 13 December 2007, EUR-Lex - 12007L/TXT

- EN https://eur-lex.europa.eu/legal-content/EN/TXT/?uri=celex\%3A12007L\%2FTXT (17.03.2020).

18 N. Moussis, Use pro spilni polityky Yevropeiskoho Soiuzu... 
The objectives of the EU Social Policy are very similar to the ones of the regional policy. The latter has the aim to improve the situation in underdeveloped regions when the social policy deals with the poorest citizens. Both EU HPs - social policy and regional policy endeavour to overcome the economic and social imbalances in the EU and to ensure an even distribution of benefits stemming from the Internal Market activities between all countries and citizens ${ }^{19}$.

Even the tax issues remain in the domain of state competences after the Lisbon Treaty, the EU Taxation policy as EU HP has gone far beyond the fiscal neutrality, firstly regulated by the EEC Treaty 1957. The Member States succeeded in replacing their various cumulative multi-stage turnover taxes with a uniform value added tax, the structures of which have been closely harmonized. The abolition of tax frontiers, made possible by the approximation of the VAT rates and excise duties, made a vital contribution to the completion of the Single Market. As Economic and Monetary Union advanced, the approximation is also required for company and savings taxes ${ }^{20}$.

The EU Competition Policy plays the role of an economic regulator in the Internal Market. It prevents market compartmentalization, which is abolished, from being restored by means of agreements between large companies. It also prevents multinational companies from exploiting their dominant position or monopolizing a market by acquisition of independent firms. Concerning the issue of State interventionism, the role of the EU competition policy is to confine it to the state aid which fits in with the joint objective of adjusting the structures of the European Union's production mechanism to internal and external changes ${ }^{21}$.

The EU Environmental Policy as EU HP is vital for the quality of life in the EU. In a European economy, which faces strong international competition, the challenge of policy-makers is to take measures that make it possible to painlessly achieve the objective of growth, which is compatible with the essential requirements of the environment. The EU follows, indeed, a coherent program for sustainable growth. However, the EU cannot work alone for the protection of the environment of the globe. Using its economic power, it should lead the way to better international coordination in this area ${ }^{22}$.

19 Ibidem.

20 Ibidem.

21 N. Moussis, Guide to European policies...

22 N. Moussis, Access to European Union... 
Thus, the EU HPs are treaty-based policies, setting-up their priorities and goals expressis verbis (Article 2, Lisbon Treaty on Functioning of the European Union). However, the EU's competences in the area of EU HPs vary very much as to the level of the EU's institutional involvement and applied policy-making methods. The EU Competition Policy, e.g. falls within the EU's exclusive competence area. Thus, the EU institutional involvement is the most crucial one with dominance of the governance methodology, formally known as the Community-based method. The EU Taxation Policy, being also treaty-based, presumes a supportive role of the EU in the achievement of joint goals and objectives within this regard being presumable achieved using intergovernmental rules for joint policy-making. Notwithstanding these peculiarities, all five types of EU HPs are aimed at the social and economic growth in the EU and its member states, so they influence the EU policy-making process as their requirements should be included in all other EU sectorial policies.

\section{Horizontal cooperation between Ukraine and the EU}

The cooperation between Ukraine and the EU in the field of horizontal policies is carried out in the context of the implementation of the AA and is regulated in TITLE IV "TRADE AND TRADE-RELATED MATTERS” (in particular, in Chapter 10 "Competition", Section 1 "Antitrust and Merges" (Art. 253-261) and Section 2 "State Aid" (Art. 262-267)) and in TITLE V "ECONOMIC AND SECTOR COOPERATION" (in particular, in Chapter 4 "Taxation" (Art. 349-354), in Chapter 6 "Environment" (Art. 360-366) and in Chapter 21 "Cooperation on employment, social policy and equal opportunities" (Art. 419-425)23.

The cooperation format is developed through the set of activities carried out by the High-level Ukraine-EU dialogue on horizontal issues and specific industrial sectors, launched in 2016 and introduced a new approach to the policy-making process in Ukraine paying more attention to the specific industrial sectors with their impact on the horizontal policies and vice-versa. In total, there have been 19 meetings of 9 working groups during the Dialogue: aviation and space, small and medium-sized

23 Uhoda pro Asotsiatsiiu mizh Ukrainoiu, z odniiei storony, ta Yevropeiskym Soiuzom, Yevropeiskym spivtovarystvom $\mathrm{z}$ atomnoi enerhii i yikhnimy derzhavamy-chlenamy, $\mathrm{z}$ inshoi storony, http://zakon2.rada.gov.ua/laws/show/984_011; EU-Ukraine Association Agreement - the complete texts, http://ukraine-eu.mfa.gov.ua/en/page/open/id/2900 (17.03.2020). 
enterprises, public procurement, textiles, technical barriers to trade, automotive, power engineering and mining ${ }^{24}$.

It was indicated that one of the additional incentives for the recovery of the Ukrainian industry should be the involvement in global, European and regional supply chains and the development of cooperation with the enterprises of the EU Member States. The goals of the High-level Ukraine-EU dialogue on horizontal issues and specific industrial sectors were introduced in 2016 by the senior political leadership of Ukraine and the EU25:

- to promote effective solutions to the problems facing the Ukrainian industry;

- to increase trust between business representatives of Ukraine and the $\mathrm{EU}$ in order to eliminate negative stereotypes about Ukraine's industrial potential;

- to ensure participation in global, European and regional supply chains, to develop cooperation with enterprises in the EU Member States, as well as to learn and apply best practices to improve industrial governance;

- the application of European quality standards in industrial production;

- to facilitate the involvement of technological and innovative solutions.

The parties consider the Dialogue as a tool of deep interaction between Ukraine and the EU, which, together with the traditional mechanisms, will also identify a powerful business component, which will facilitate the establishment of direct contacts between business associations of Ukraine and the EU and will help domestic industrialists to interact with their counterparts from the EU member states. Ukraine's participation in the Dialogue will also serve as a complementary element to the

24 EU-Ukraine High Level Dialogue on Horizontal Issues and Industries https://www.me.gov. ua/Documents/Detail?lang $=$ uk-UA\&id $=$ c6909e54-df9c-4868-abd0-70d55da60a7e\&title =D ialogVisokogoRivniaUkrainasSchodoGorizontalnikhPitanTaOkremikhSektorivPromislovosti (17.03.2020).

25 Dialoh Ukraina - YeS vysokoho rivnia shchodo horyzontalnykh pytan ta okremykh sektoriv promyslovosti, Departament mizhnarodnoho torhovelno-ekonomichnoho spivrobitnytstva ta yevropeiskoi intehratsii, http://www.me.gov.ua/Documents/Detail?lang=ukUA\&id=bb996857-88dd-4326-8249-3d74069542e1\&title=DialogUkrainasVisokogoRivniaS chodoGorizontalnikhPitanTaOkremikhSektorivPromislovosti (17.03.2020). 
functioning of the National Committee on Industrial Development and its Expert Council26.

The first inaugural meeting of the EU-Ukraine Dialogue was held in Brussels on 1-2 March 2017, within which a meeting of 5 working groups occurred touching the following issues:

- on the removal of technical barriers to trade and standardization;

- small and medium-sized enterprises;

- space cooperation;

- public procurement;

- automotive industry.

Such potential directions of cooperation between Ukraine and the EU have been defined:

- an in-depth targeted regulatory approximation with a focus on participation in European value chains;

- industrial outsourcing;

- greater involvement of Ukraine in the Horizon 2020 and COSME programs;

- exchange of the latest technologies 27.

The second meeting of the Working Group on Industry (Textile Industry) was held on December 4, 2017. Therefore the second meeting of the Working Group on Technical Barriers to Trade and Standardization was held on December 7, 2017.

The Dialogue has become a platform for the exchange of information and best practices on ways of modernization and industrial restructuring of Ukraine and improvement of framework conditions for enterprises, in particular, SMEs. In the future, the Dialogue will also help to reduce technical barriers to trade by harmonizing the normative and technical standards of Ukraine and the EU. The working groups discussed technical barriers to trade and standardization, public procurement, small and medium-sized business policy, engineering, the automotive industry and space cooperation. Due to the work of the Dialogue in October 2017,

26 Dialoh Ukraina - YeS vysokoho rivnia shchodo horyzontalnykh pytan ta okremykh sektoriv promyslovosti, Departament mizhnarodnoho torhovelno-ekonomichnoho spivrobitnytstva ta yevropeiskoi intehratsii, http://www.me.gov.ua/Documents/Detail?lang=ukUA\&id=bb996857-88dd-4326-8249 (17.03.2020).

27 Dialoh Ukraina - YeS vysokoho rivnia shchodo horyzontalnykh pytan ta okremykh sektoriv promyslovosti, Departament mizhnarodnoho torhovelno-ekonomichnoho spivrobitnytstva ta yevropeiskoi intehratsii, http://www.me.gov.ua/Documents/Detail?lang=ukUA\&id=bb996857-88dd-4326-8249-3d74069542e1\&title=DialogUkrainasVisokogoRivniaS chodoGorizontalnikhPitanTaOkremikhSektorivPromislovosti\&isSpecial=true (17.03.2020). 
Ukraine was granted an observer status in the EC Expert Raw Materials Supply Group ${ }^{28}$.

The High-Level Ukraine-EU Dialogue in Horizontal and Specific Industrial Sectors was held in Kyiv on March 27, 2018. During the event, the parties approved the Dialogue Roadmap. The actions shown in it are not exhaustive. Therefore, this document will remain open to new joint initiatives. Besides, 5 Working Groups were held as a part of the Second Dialogue: automotive industry; small and medium-sized business; space; public procurement; technical barriers to trade and standardization.

The following steps were approved:

- cooperation within the approved Dialogue Roadmap;

- implementation of the operational conclusions reached in the discussions of the relevant Working Groups;

- launching additional activities within the Working Group on Industry (directions are to be specified);

- establishment of permanent consultation mechanisms on industrial cooperation with the EU Member States and other countries of the world 29 .

All these measures allow to be involved in the best practices in the formulation and implementation of the EU horizontal policies and effectively implement this practice in Ukraine.

In 2018, Ukraine has significantly strengthened its institutional capacity to execute and monitor the AA implementation. To accelerate the adoption of European integration legislation, on February 28, 2018, the Roadmap for Legislative Support for the Implementation of the Association Agreement was approved. The constructive dialogue and effective coordination between the Parliament and the Government within the framework of the Roadmap are playing a crucial role in the implementation of the Agreement. As a result, by the end of 2018, within the above-mentioned Roadmap, the Verkhovna Rada of Ukraine (Ukrainian

28 Dialoh Ukraina - YeS vysokoho rivnia shchodo horyzontalnykh pytan ta okremykh sektoriv promyslovosti, Departament mizhnarodnoho torhovelno-ekonomichnoho spivrobitnytstva ta yevropeiskoi intehratsii, http://www.me.gov.ua/Documents/Detail?lang=ukUA\&id=bb996857-88dd-4326-8249-3d74069542e1\&title=DialogUkrainasVisokogoRivniaS chodoGorizontalnikhPitanTaOkremikhSektorivPromislovosti\&isSpecial=true (17.03.2020).

29 Dialoh Ukraina - YeS vysokoho rivnia shchodo horyzontalnykh pytan ta okremykh sektoriv promyslovosti, Departament mizhnarodnoho torhovelno-ekonomichnoho spivrobitnytstva ta yevropeiskoi intehratsii, http://www.me.gov.ua/Documents/Detail?lang=ukUA\&id=bb996857-88dd-4326-8249-3d74069542e1\&title=DialogUkrainasVisokogoRivniaS chodoGorizontalnikhPitanTaOkremikhSektorivPromislovosti\&isSpecial=true (17.03.2020). 
Parliament) adopted 11 European integration laws in the second reading and 10 in the first reading ${ }^{30}$.

The regular meeting of the EU-Ukraine High Level Dialogue on Horizontal Issues and Specific Sectors of Industry was held in Brussels on March 12, 2019 with the participation of representatives of the State Space Agency of Ukraine, State Enterprise "Pivdenne Design Office", the Government Office for Coordination of Euro-Atlantic integration and representatives of the European Commission. The parties discussed cooperation on the Copernicus, Galileo, Egnos programs and Ukraine's participation in the Horizon2020 space segment ${ }^{31}$.

In the future, the Dialogue will also help to reduce technical barriers to trade by harmonizing the normative and technical standards of Ukraine and the EU.

The current priorities of the Dialogue include technical regulation as a prerequisite for the conclusion of the Agreement on Conformity Assessment and Acceptability of Industrial Goods (ASAA Agreement), public procurement, SMEs, raw materials (mining), space industry and civil aviation.

In the framework of the $21^{\text {st }}$ Ukraine-EU Summit held in Kyiv, an important agreement was signed. The purpose of the Agreement between the Government of Ukraine and the European Commission on the financing of the event "Technical Cooperation Program 2019" is to involve the assistance of the European Union to support Ukraine in the implementation of key reforms and implementation of the provisions of the Association Agreement between Ukraine and the EU in the area of deep and comprehensive free trade area (DCFTA) in the selected priority areas (in particular, agriculture, environment, energy, public procurement, business and investment climate, trade, labour relations) ${ }^{32}$.

30 Zvit pro vykonannia Uhody pro Asotsiatsiiu mizh Ukrainoiu ta Yevropeiskym Soiuzom (za 2018 rik) https://eu-ua.org/sites/default/files/inline/files/association-agreement-implementation-report-2018.pdf (17.03.2020).

31 Meeting of the EU-Ukraine High Level Dialogue Working Group on Space Cooperation held in Brussels, https://ukraine-eu.mfa.gov.ua/news/71111-u-bryusseli-vidbulosy-zasidannya-robochoji-grupi-z-pitany-spivpraci-u-kosmichnij-sferi-u-ramkah-dialogu-visokogo-rivnyaukrajinajes (17.03.2020).

32 Ukraine and the EU signed five financing agreements - summit decisions, https://www. ukrinform.ua/rubric-polytics/2735993-ukraina-ta-es-pidpisali-pat-finansovih-ugod-risennasamitu.html (17.03.2020). 
The new sets of activities within horizontal policies are foreseen for Ukraine in the Transition Book 201933. For example, in the sphere of Regional Policy Ukraine should do as following: attraction in the regions of Ukraine transport and border infrastructure, foreign investment and EU assistance; development of the Euroregions; implementation of Twin Cities Initiatives; maximum involvement of regions in educational, EU scientific, cultural projects/programs; support for small and mediumsized businesses in the regions, including the $\mathrm{EU}$, in particular, within the framework of the EaP policy.

On the $20^{\text {th }}$ of November, 2019, the Information and Analytical System for monitoring the implementation of the Association Agreement "Agreement Pulse" was opened for free access 34 . "Pulse of the Agreement" provides a total of about 8 thousand activities distributed over 2 thousand tasks. In the process of monitoring the implementation of the Agreement, each measure is assigned a status of "completed" or "not completed". The status of implementation of measures is traced to the main contractors - the relevant authorities, which enables to understand from whom at a particular moment depends on the fulfilment of the obligation. There are two types of metrics in the report: fulfilment of commitments with a maturity of 2019 year (current progress) and overall commitment progress up to 2024. Current progress is calculated as a percentage and shows the proportion of activities completed within each year, as a whole, and in terms of 24 spheres. It reflects what proportion of events are planned per year, as of the date of the assessment ${ }^{35}$.

According to the Report 2019, the EU-Ukraine AA implementation is carried out in the context of the Sustainable Development Goals, as a comprehensive and human-centered package of goals and objectives that, in a balanced and integrated manner, ensure sustainable development in its three dimensions - economic, social and environmental. It is these three components - the Association Agreement, the Copenhagen Criteria, and the Sustainable Development Goals - that are a sure guide to Ukraine's successful long-term development, to ensure the well-being and prosperity of all citizens ${ }^{36}$.

33 European and Euro-Atlantic integration. Transition book 2019 http://pulse.eu-ua.org/sites/ default/files/field/files/docs/transition_book.pdf (17.03.2020).

34 Zvit provykonannia Uhody pro asociaciiu mizh Ukrainoiu ta YeS za 2019 rik https://www. kmu.gov.ua/storage/app/sites/1/55-GOEEI/ar-aa-implementation-2019-4.pdf (17.03.2020).

35 Puls Uhody - monitoring realizaciii planu zahodiv z vykonannia Uhody Угоди, http://pulse. eu-ua.org (17.03.2020).

36 Zvit provykonannia Uhody pro asociaciiu mizh Ukrainoiu ta YeS za 2019 rik https://www. kmu.gov.ua/storage/app/sites/1/55-GOEEI/ar-aa-implementation-2019-4.pdf (17.03.2020). 
Within the framework of the European Green Agreement, Ukraine and the EU have agreed to bring together "environmental agendas", which will allow them to work together on the environmental challenges facing humanity. Ukraine is already working in this area and has set up an interagency working group. For the first time, European integration has become a transparent, measurable, and accountable public policy in Ukraine. The decision of the Government Agreement Pulse - a tool for planning, monitoring and evaluating the performance of the Association Agreement - became public and now every citizen can find out how the Association Agreement is implemented in Ukraine.

The next Dialogue meeting, in conjunction with the Economic Growth Mission, is planned to be held in 2020 - a special visit to Ukraine by high-level European Commission officials and representatives of influential European businesses to deepen ties between business circles. The importance of implementation of reforms and cooperation in the energy sector was emphasized for the creation of a common aviation space, decarbonisation and environmental protection.

\section{Conclusions}

The EU CPs are rooted into the ideas of economic integration within the EU, developed and directed to economic growth and social progress in the EU Internal Market as foreseen in the Article 3(3) of the Lisbon Treaty. As a governance phenomenon, based on the delegation of national powers and functions to the EU institutions, and reflected in the EU constituent treaties and other regulatory documents, each EU CP has its features, governance models based on specific decision-making rules and practices in the $\mathrm{EU}$, the involvement of the $\mathrm{EU}$ institutions. Being embedded into the EU founding treaties and other regulatory documents, the EU CPs also differ as to the level of the competences being vested to the EU for fulfilment of EU CPs' objectives.

The EU CPs are linked with the governance models in the EU and reflect the EU and EU Member States interactions models for achieving the joint objectives of the European integration as reflected in the EU constituent treaties. The EU CPs have contractual nature and are linked both to the EU powers and policy-making rules. As the main criteria for the EU CPs classification can be suggested their embedment into the EU legal framework (foreseen or not foreseen in the EU founding treaties), the level of the institutional involvement from the EU side 
and their Member States to policy development and policy realization as well as their monosectoral or cross-sectoral impact within the development of the EU economic model. The EU HPs are the most evident cross-sectoral links and impact, since they cover such areas as regional development, social policy, competition, taxation and environment.

Thus, the EU HPs are treaty-based policies, setting-up their priorities and goals expressis verbis (Art. 2 of Lisbon Treaty). However, EU's competences in the area of EU HPs vary very much as to the level of the EU's institutional involvement and applied policy-making methods. Notwithstanding these peculiarities, all five types of EU HPs are aimed at the social and economic growth in the EU and its member states, so they influence the EU policy-making process as their requirements should be included in all other EU sectorial policies.

Cooperation between Ukraine and the EU in the field of horizontal policies is carried out in the context of the implementation of the AA. The cooperation between Ukraine and the EU in the EU HPs is developed in the format of the activities carried out by the High-level Ukraine-EU Dialogue on horizontal issues and specific industrial sectors, which was launched in 2016 and introduced new approach to the policy-making process in Ukraine based on payment of more attention to the specific industrial sectors with their impact on the horizontal policies and vice-versa. In the future, the Dialogue will also help to reduce technical barriers to trade by harmonizing the normative and technical standards of Ukraine and the EU. The current priorities of the Dialogue include technical regulation as a prerequisite for the conclusion of the Agreement on Conformity Assessment and Acceptability of Industrial Goods (ASAA Agreement), public procurement, SMEs, raw materials (mining), space industry and civil aviation.

Taking into the account all these issues we can affirm that the European Union will demand from Ukraine the same style and understanding of policy-making process as it has for its Member States. The models of policy making will influence the style of the EU-Ukraine interaction toward the Association Agreement implementation on the way of law approximation and implementation of the European standards and norms. Ukrainian government should pay attention to this issue while negotiation the issues of the EU-Ukraine cooperation in different spheres.

Therefore, the implementation of the objectives required to achieve the goals of the Association Agreement should change the quality of every citizen's life and represents Ukraine's day-to-day integration into 
the EU. European integration became a must for the Ukrainians irrespective of political choices and attitudes. The successful implementation of the Association Agreement will allow both raising the issue of membership and ensuring an explicit response to that question. Ukraine steadily follows the European way, which should ensure national unity and prosperity.

\section{Bibliography}

I.A. Hrytsiak, Osoblyvosti yevropeiskoho upravlinnia na natsionalnomu rivni: metodychnyi aspect, «Stratehichni priorytety» 2007, No. 1(2).

O.A. Krayevska, Transformatsiia modelei formuvannia spilnykh polityk YeS u kompetentsii YeS za Lisabonskym dohovorom, «Visnyk Lvivskoho universytetu. Seriia mizhnarodni vidnosyny» 2016, vyp. 38.

O.A. Krayevska, Common Policies of the European Union, [in:] M. Malskyy, Y. Moroz (eds.), International Relations: Politics. Economics. Law, LNU Franka, Lviv 2017 (in Ukrainian).

M. Malskyy, N. Antonyuk, M. Gladysh, O. Krayevska, Regionalism and spillover effects: case of Ukraine, [in:] O. Bogdanova, A. Makarychev (eds.), Baltic - Black Sea Regionalism: Patchworks and Networks at Europe's Eastern Margins, Springer, Tartu 2020.

N. Moussis, Access to European Union: law, economics, policies, Rixensart 2011, http://europedia.moussis.eu/about/?book $=$ B0001

N. Moussis, Guide to European policies, European Study Service, Rixensart 2005.

N. Moussis, Use pro spilni polityky Yevropeiskoho Soiuzu, K.I.S, Kyiv 2005.

V. Muraviov, Vydy kompetentsii reformovanoho Yevropeiskoho Soiuzu, «Visnyk Kyivskoho natsionalnoho universytetu imeni Tarasa Shevchenka. Seriia mizhnarodni vidnosyny» 2009, vyp. 37, www.nbuv.gov.ua/portal/natural/vknu/mv/2009_37.pdf

H. Wallace, W. Wallace, M. Pollack (eds.), Policy-Making in the European Union, Oxford University Press 2005.

W. Wallace, Tvorennia polityky v Yevropeiskomu Soiuzi, Osnovy, Kyiv 2004. 